\title{
DETERMINAN PENGUNGKAPAN ISLAMIC SOCIAL REPORTING PERUSAHAAN YANG TERGABUNG DI JAKARTA ISLAMIC INDEX
}

\author{
Lukman Effendy1, Email : 1ukman.effendy@unram.ac.id \\ Zuhrotul Isnaini², Email : zuhrotul.isnaini@unram.ac.id \\ Isnawati ${ }^{3}$,Email : isnawati.isnawati@unram.ac.id \\ ${ }^{123}$ Faculty of Economics and Business, Mataram University,
}

\begin{tabular}{|c|c|}
\hline ARTICLE INFO & ABSTRACT \\
\hline 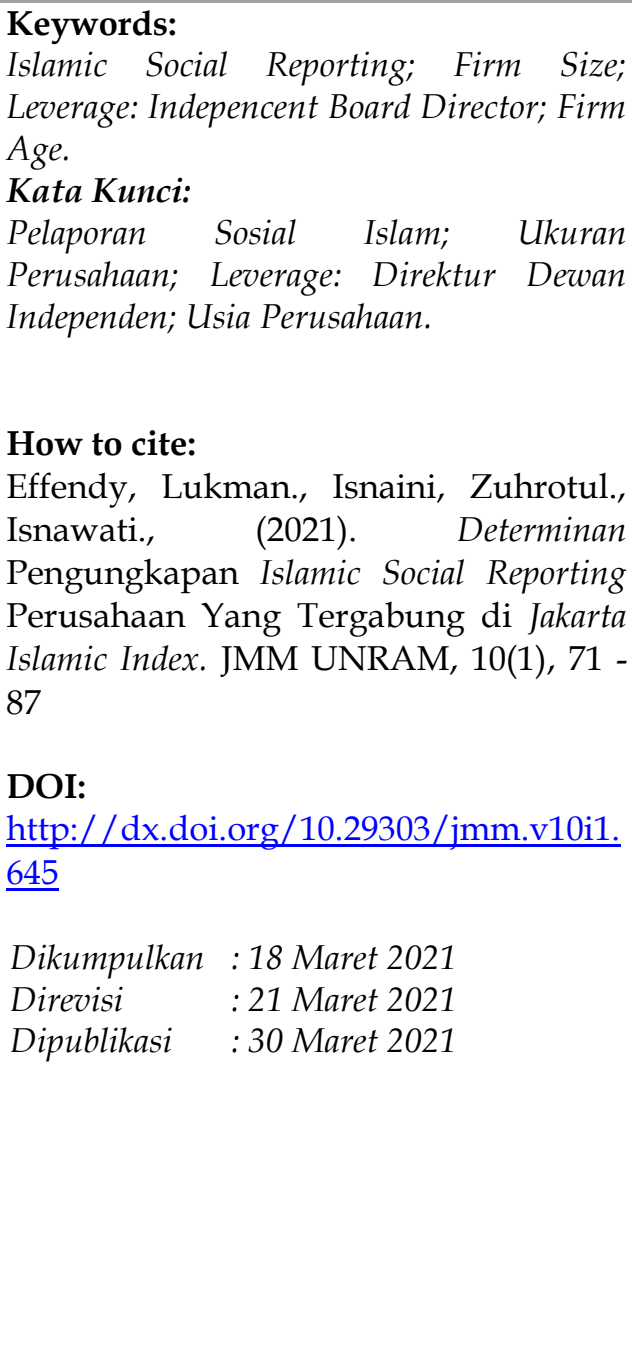 & $\begin{array}{l}\text { This study aims to examine the determinants of the } \\
\text { disclosure of Islamic social reporting of companies } \\
\text { incorporated in the Jakarta Islamic Index. ISR } \\
\text { determinants in this study are company size, } \\
\text { profitability, leverage, board size, and company age. } \\
\text { The population used in this study were all companies } \\
\text { listed on the Jakarta Islamic Index (JII) for the period } \\
2016 \text { to 2018. The sampling method used was } \\
\text { purposive sampling with a sample size of } 51 \text { company } \\
\text { years. Data panel regression is used to achieve the } \\
\text { goal. The results showed that company size, leverage, } \\
\text { and the independent board of commissioners had a } \\
\text { significant effect on the disclosure of Islamic social } \\
\text { reporting. Meanwhile, profitability and company age } \\
\text { show the opposite result. } \\
\text { Penelitian ini bertujuan untuk menguji determinan } \\
\text { pengungkapan Islamic social reporting pada } \\
\text { perusahaan yang tergabung dalam Jakarta Islamic } \\
\text { Index. Determinan ISR dalam penelitian ini adalah } \\
\text { ukuran perusahaan, profitabilitas, leverage, ukuran } \\
\text { dewan komisaris, dan umur perusahaan. Populasi } \\
\text { yang digunakan dalam penelitian ini adalah seluruh } \\
\text { perusahaan yang terdaftar di Jakarta Islamic Index } \\
\text { (JII) periode 2016 hingga 2018. Metode pengambilan } \\
\text { sampel yang digunakan adalah purposive sampling } \\
\text { dengan ukuran sampel } 51 \text { tahun perusahaan. Regresi } \\
\text { panel data digunakan untuk mencapai tujuan. Hasil } \\
\text { penelitian menunjukkan bahwa ukuran perusahaan, } \\
\text { leverage, dan dewan komisaris independen } \\
\text { berpengaruh signifikan terhadap pengungkapan } \\
\text { Islamic Social Reporting. Sedangkan profitabilitas dan } \\
\text { umur perusahaan menunjukkan hasil yang sebaliknya. }\end{array}$ \\
\hline & $\begin{array}{l}\text { Copyright }(9 \text { 2021. Lukman Effendy, Zuhrotul } \\
\text { Isnaini, Isnawati. All rights reserved. }\end{array}$ \\
\hline
\end{tabular}




\section{PENDAHULUAN}

Data Bursa Efek Indonesia (BEI) pada tahun 2018 menyatakan bahwa jumlah investor syariah di Indonesia tumbuh sebanyak 92\% menjadi 44.536 investor dari capaian tahun sebelumnya hanya 23.207 investor (www.idx.co.id). Selain itu, pada Maret 2018, Indonesia juga menjadi negara pertama yang menerbitkan sovereign green sukuk di dunia senilai US\$ 1,25 miliar (www.ojk.go.id). Green sukuk adalah sebuah instrumen investasi yang penggunaannya untuk memenuhi mandat kepedulian lingkungan dan kepatuhan syariah. Hal ini membuktikan bahwa pasar modal syariah mendapatkan tanggapan yang positif dari masyarakat di tengah banyaknya pasar modal konvensional yang ada.

Sejalan dengan pertumbuhan pasar modal syariah yang pesat, maka diikuti pula dengan tanggung jawab yang besar. Salah satu bentuk tanggung jawab itu adalah melakukan pengungkapan tanggung jawab sosial atau Corporate Social Responsibility (CSR). Didasarkan konsep syariah, muncul konsep baru dalam CSR yang disebut Islamic Social Reporting. Konsep Islamic Social Reporting (ISR) ini pertama kali dikemukakan oleh Haniffa (2002). Ia mengungkapkan bahwa adanya keterbatasan dalam pelaporan sosial konvensional sehingga mengemukakan kerangka konseptual ISR berdasarkan ketentuan syariah yang tidak hanya membantu pengambilan keputusan bagi pihak muslim melainkan juga untuk membantu perusahaan dalam melakukan pemenuhan kewajiban sosial kepada masyarakat sekaligus memberikan kepuasan spiritual bagi investornya. Berdasarkan penelitian terdahulu, luas pengungkapan ISR dipengaruhi oleh beberapa faktor yaitu ukuran perusahaan, profitabilitas, leverage, ukuran dewan komisaris independen,

Salah satu faktor yang mempengaruhi pengungkapan ISR adalah ukuran perusahaan (Ayu, 2010). Perusahaan yang lebih besar adalah perusahaan yang memiliki sumber daya lebih banyak daripada perusahaan yang lebih kecil. Fakta ini dibuktikan dengan penelitian yang dilakukan Raditya (2012), Maulida dkk (2014), Firmansyah \& Eko Haryanto (2014), Putri \& Yuyetta (2014), Rama \& Meliawati (2014), Santoso \& Zaki (2017), Rizfani \& Lubis (2018), menemukan hubungan positif ukuran perusahaan (size) terhadap ISR, Hal ini bertolak belakang dengan penelitian Rahayu (2014), Miskiyah (2016), yang menemukan bahwa ukuran perusahaan tidak berpengaruh terhadap luasnya pengungkapan ISR.

Profitabilitas juga mempengaruhi pengungkapan ISR (Rizfani \& Lubis, 2018). Perusahaan yang berada pada posisi menguntungkan akan cenderung melakukan pengungkapan informasi yang lebih luas dalam laporan tahunannya. Penelitian Ayu (2010), Raditya (2012), Maulida dkk (2014), Firmansyah \& Eko Haryanto (2014), Putri \& Yuyetta (2014), Rizfani \& Lubis (2018) menemukan bahwa profitabilitas berpengaruh positif dan signifikan terhadap ISR. Namun dalam penelitian Rahayu (2014), Rama \& Meliawati (2014), Rosiana et. al (2015), Miskiyah (2016), Santoso \& Zaki (2017), Sutapa \& Heri (2018) profitabilitas tidak berpengaruh terhadap luas informasi pada pengungkapan ISR.

Leverage timbul karena perusahaan dalam operasinya menggunakan aktiva dan sumber dana yang menimbulkan beban tetap bagi perusahaan. Penelitian Rama \& Meliawati (2014) dan Rizfani \& Lubis (2018) menemukan bahwa leverage berpengaruh negatif terhadap pengungkapan ISR. Bertolak belakang dengan penelitian Rosiana et. al (2015) dan Rahayu (2014) menemukan bahwa leverage tidak berpengaruh terhadap pengungkapan ISR.

Ukuran dewan komisaris independen merupakan jumlah anggota dewan komisaris independen dalam suatu perusahan (Sembiring 2005). Semakin besar ukuran 
dewan komisaris independen, maka pengawasan akan semakin baik. Firmansyah \& Haryanto (2014) bahwa dewan komisaris independen berpengaruh signifikan positif terhadap pengungkapan ISR, akan tertapi berbeda dengan penelitian Rahayu (2014), Miskiyah (2016) bahwa dewan komisaris independen tidak berpengaruh terhadap pengungkapan ISR.

Perusahaan dengan umur yang lebih muda diprediksi akan melakukan penyebaran informasi yang lebih banyak dibandingkan perusahaan dengan umur yang lebih tua. Berdasarkan penelitian Rizfani \& Lubis (2018) bahwa umur perusahaan berpengaruh terhadap pengungkapan ISR, sedangkan penelitian Raditya (2012) menemukan bahwa umur perusahaan tidak berpengaruh terhadap pengungkapan ISR, di mana bahwa perusahaan dengan umur yang lebih tua tidak menjamin melakukan pengungkapan tanggung jawab sosial secara syariah lebih luas. Sebaliknya, perusahaan syariah dengan umur yang lebih muda juga belum tentu melakukan pengungkapan tanggung jawab sosial secara syariah yang lebih kecil dibandingkan dengan perusahaan dengan umur yang lebih tua.

Berdasarkan uraian diatas, peneliti tertarik untuk melakukan penelitian dengan mengambil judul "Determinan Pengungkapan Islamic Social Reporting pada Perusahaan Tergabung di Jakarta Islamic Index".

\subsection{Rumusan Masalah}

Berdasarkan uraian pada latar belakang, maka dapat dirumuskan permasalahan dalam penelitian ini adalah:

1. Apakah ukuran perusahaan memiliki pengaruh terhadap pengungkapan Islamic Social Reporting?

2. Apakah profitabilitas memiliki pengaruh terhadap pengungkapan Islamic Social Reporting?

3. Apakah leverage memiliki pengaruh terhadap pengungkapan Islamic Social Reporting?

4. Apakah ukuran dewan komisaris independen memiliki pengaruh terhadap pengungkapan Islamic Social Reporting?

5. Apakah umur perusahaan memiliki pengaruh terhadap pengungkapan Islamic Social Reporting?

\subsection{Tujuan dan Manfaat Penelitian}

\subsubsection{Tujuan Penelitian}

Berdasarkan uraian pada latar belakang dan rumusan masalah, maka tujuan dari penelitian ini adalah:

1. Untuk mengetahui pengaruh ukuran perusahaan terhadap pengungkapan Islamic Social Reporting.

2. Untuk mengetahui pengaruh profitabilitas terhadap pengungkapan Islamic Social Reporting.

3. Untuk mengetahui pengaruh leverage terhadap pengungkapan Islamic Social Reporting.

4. Untuk mengetahui pengaruh dewan komisaris independen terhadap pengungkapan Islamic Social Reporting.

5. Untuk mengetahui pengaruh umur perusahaan terhadap pengungkapan Islamic Social Reporting. 


\subsubsection{Manfaat Penelitian}

Berdasarkan tujuan penelitian dan uraian pada latar belakang, maka hasil dari penelitian ini nantinya diharapkan dapat memberikan manfaat dalam memberikan pandangan baru kepada investor untuk menilai kinerja perusahaan dan dapat dijadikan dasar pengambilan keputusan investasi.

\section{TINJAUAN PUSTAKA}

\subsection{Konsep Islamic Social Reporting (ISR)}

Indeks ISR adalah perluasan dari social reporting yang meliputi harapan masyarakat tidak hanya mengenai peran perusahaan dalam perekonomian, tetapi juga peran perusahaan dalam perspektif spiritual (Haniffa, 2002). Ada beberapa hal yang penting dalam social reporting menurut perspektif islam, yaitu pemahaman mengenai akuntabilitas, keadilan sosial, dan kepemilikan sosial (Maali et al., 2006).

Indeks ISR berisi kompilasi item-item standar tanggung jawab sosial yang ditetapkan oleh AAOIFI (Accounting and Auditing Organization for Islamic Financial Institutions) yang kemudian dikembangkan lebih lanjut oleh para peneliti mengenai item-item tanggung jawab sosial yang seharusnya diungkapkan oleh suatu entitas Islam (Rina Trisnawati \& Azhar, 2013). Berikut adalah enam kriteria pengungkapan dalam kerangka indeks ISR yang digunakan dalam penelitian ini:

1. Pendanaan dan Investasi yang terdiri atas: riba (interest-free); gharar (ketidakpastian); zakat; kewajiban atas keterlambatan pembayaran piutang dan penghapusan piutang tak tertagih; Value Added Statement. Value added (nilai tambah) sebagai nilai yang tercipta dari hasil aktivitas perusahaan dan karyawan-karyawan, sedangkan value added statement merupakan pernyataan yang melaporkan perhitungan nilai tambah tersebut serta aplikasi di antara para pemangku kepentingan perusahaan.

2. Produk dan Jasa yang terdiri atas: produk yang ramah lingkungan; status kehalalan produk; kualitas dan keamanan suatu produk; pelayanan pelanggan; Glossary.

3. Karyawan, yaitu masyarakat Islam ingin mengetahui apakah karyawan-karyawan perusahaan telah diperlakukan secara adil dan wajar melalui informasi-informasi yang diungkapkan, seperti upah, karateristik pekerjaan, jam kerja per hari, libur tahunan, jaminan kesehatan dan kesejahteraan, kebijakan terkait waktu dan tempat ibadah, pendidikan dan pelatihan, kesetaraan hak, dan lingkungan kerja (Haniffa, 2002). Selain itu, Haniffa \& Hudaib (2007) juga menambahkan beberapa aspek pengungkapan berupa jumlah karyawan yang dipekerjakan dan penghargaan kepada pekerja.

4. Masyarakat, di mana Haniffa (2002), menerangkan bahwa konsep dasar yang mendasari tema ini adalah ummah, amanah, dan adil.

5. Lingkungan (Environment). Islam mengajarkan kepada seluruh umatnya untuk menjaga, memelihara, dan melestarikan bumi beserta isinya. Dengan kata lain, perusahaan tidak seharusnya terlibat dalam aktivitas-aktivitas yang merusak dan membahayakan lingkungan (Haniffa 2002). Oleh karena itu, informasi-informasi yang berhubungan dengan penggunaan sumber daya dan program-program yang digunakan untuk melindungi lingkungan harus diungkapkan dalam laporan tahunan perusahaan (Othman \& Thani, 2010).

6. Tata Kelola Perusahaan 


\subsection{Pengembangan Hipotesis}

\subsubsection{Ukuran Perusahaan dan Pengungkapan Islamic Social Reporting}

Semakin besar ukuran perusahaan, biasanya informasi yang tersedia untuk investor dalam pengambilan keputusan sehubungan dengan investasi dalam perusahaan tersebut semakin banyak (Siregar dan Utama, 2005). Pengungkapan sosial yang lebih besar merupakan pengurangan biaya politis bagi perusahaan (Hasibuan, 2001). Selain itu, perusahaan yang berukuran lebih besar cenderung memiliki public demand terhadap informasi yang lebih tinggi dibanding perusahaan yang berukuran lebih kecil.

Penelitian Ayu (2010), Raditya (2012), Maulida dkk (2014), Firmansyah \& Eko Haryanto (2014), Putri \& Yuyetta E.N.A (2014), Rama \& Meliawati (2014), Santoso \& Zaki (2017), Rizfani \& Lubis (2018), telah membuktikan bahwa ukuran perusahaan memiliki pengaruh positif terhadap tingkat pengungkapan ISR. Atas dasar pemikiran tersebut, penelitian ini memprediksi bahwa perusahaan yang lebih besar akan cenderung melakukan pengungkapan tanggung jawab sosial secara syariah yang lebih luas. Sejalan dengan penelitian tersebut yang pernah dilakukan, maka hipotesis yang dapat dirumuskan adalah sebagai berikut:

Hipotesis 1: Ukuran Perusahaan berpengaruh positif terhadap pengungkapan Islamic Social Reporting di perusahaan go public yang listing di Jakarta Islamic Index

\section{Profitabilitas dan Pengungkapan Islamic Social Reporting}

Dari perspektif Islam, perusahaan harus bersedia untuk memberikan pengungkapan penuh tanpa melihat apakah perusahaan memberikan keuntungan atau tidak (Haniffa, 2002). Namun, Janggu (2004) berpendapat bahwa perusahaan dengan profiatabilitas yang lebih tinggi kemungkinan akan mengungkapkan informasi yang lebih dibandingkan perusahaan dengan profitabilitas yang kurang.

Perusahaan dengan profitabilitas yang lebih tinggi kemungkinan akan mengungkapkan informasi yang lebih dibandingkan perusahaan dengan profitabilitas yang kurang tinggi. Hal tersebut sesuai dengan penelitian Ayu (2010), Raditya (2012), Maulida dkk (2014), Firmansyah \& Eko Haryanto (2014), Putri \& Yuyetta E.N.A (2014), Rizfani \& Lubis (2018) menemukan bahwa profitabilitas berpengaruh positif terhadap ISR. Berdasarkan hasil penelitian terdahulu dan pembahasan di atas, maka hipotesis yang dapat dirumuskan adalah sebagai berikut:

Hipotesis 2: Profitabilitas berpengaruh positif terhadap pengungkapan ISR di perusahaan go public yang listing di Jakarta Islamic Index

\subsubsection{Leverage}

Struktur modal dari sebuah perusahaan yang dapat mempengaruhi pengeluaran atas biaya laporan tanggung jawab sosial perusahaan. saat perusahaan mempunyai utang bunga yang tinggi, kemampuan manajemen berinvestasi lebih pada program laporan pertanggung jawaban sosial perusahaan (CSR) adalah terbatas. Penelitian Rama \& Meliawati (2014), Rizfani \& Lubis (2018) menemukan bahwa leverage berpengaruh negatif terhadap pengungkapan ISR. Berdasarkan penjelasan di atas, maka dapat dirumuskan hipotesis sebagai berikut:

Hipotesis 3: Leverage berpengaruh negatif terhadap pengungkapan Islamic Social Reporting di perusahaan go public yang listing di Jakarta Islamic Index

\subsubsection{Dewan Komisaris Independen}

Komisaris Independen merupakan anggota Dewan Komisaris yang tidak memiliki hubungan keuangan, kepengurusan, kepemilikan saham dan atau hubungan keluarga dengan anggota Dewan Komisaris lainnya dan atau dengan Pemegang Saham atau 
hubungan lainnya dengan Perseroan yang dapat mempengaruhi kemampuannya bertindak independen.

Said et al., (2009) menyatakan bahwa semakin besar jumlah anggota dewan komisaris, maka akan semakin mudah untuk mengendalikan CEO dan monitoring yang dilakukan akan semakin efektif. Dikaitkan dengan pengungkapan tanggung jawab sosial, maka tekanan terhadap manajemen juga akan semakin besar untuk mengungkapkannya. Selaras dengan penelitian Firmansyah \& Eko Haryanto (2014) bahwa ukuran dewan komisaris berpengaruh positif terhadap pengungkapan ISR. Berdasarkan penjelasan yang telah dikemukakan, maka hipotesis yang dapat dirumuskan adalah sebagai berikut:

Hipotesis 4: Ukuran dewan komisaris independen berpengaruh positif terhadap Islamic Social Reporting di perusahaan go public yang listing di Jakarta Islamic Index.

\subsubsection{Umur Perusahaan}

Ketepatan dalam pelaporan keuangan oleh perusahaan dipengaruhi oleh usia (yaitu pengembangan dan pertumbuhan). Karena itu, perusahaan profesional yang memiliki umur lebih tua cenderung lebih profesional dalam pengumpulan, pengolahan dan penyediaan informasi ketika diperlukan karena pengalaman perusahaan (Owusu \& Ansah, 2002). Keinginan para pemegang saham dan pemangku kepentingan yang lainnya akan lebih mudah dipahami pada saat perusahaan tersebut secara usia lebih tua. Perusahaan yang sudah lama berdiri akan selalu menjaga stabilitas dan citra perusahaan (Prasetyoningrum, 2018). Untuk menjaga stabilitas dan citra, perusahaan akan berusaha mempertahankan dan meningkatkan kinerjanya, salah satunya adalah dengan pengungkapan ISR. Berdasarkan penjelasan yang telah dikemukakan, maka hipotesis yang dapat dirumuskan adalah sebagai berikut:

Hipotesis 5: Umur perusahaan berpengaruh positif terhadap Islamic Social Reporting di perusahaan go public yang listing di Jakarta Islamic Index.

\subsection{Rerangka Konseptual}

Gambar 1 berikut ini mengilustrasikan rerangka yang akan mendukung dalam penelitian. Rerangka konseptual ini akan menjelaskan lima faktor perusahaan yang berpengaruh untuk mengungkapkan Islamic Social Reporting (ISR).

\section{Gambar 1.}

\section{Rerangka Konseptual}

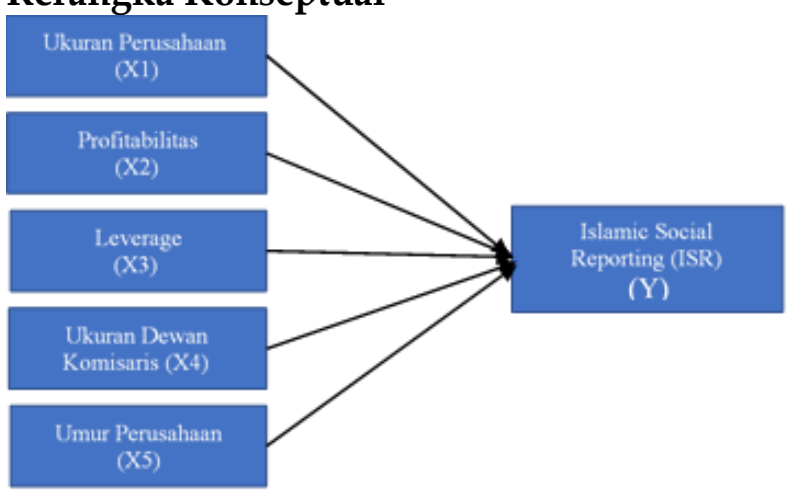

\section{METODE PENELITIAN}

Metode penelitian yang akan digunakan dalam penelitian ini adalah metode asosiatif dengan pendekatan kuantitatif. Metode asosiatif merupakan metode yang bermaksud untuk menjelaskan hubungan kausal dan pengaruh antara variabel-variabel melalui pengujian hipotesis (Sugiyono, 2017;11). Penelitian ini menggunakan data 
sekunder yang tersedia di Jakarta Islamic Index (JII). Obyek penelitian yang digunakan pada penelitian ini adalah perusahaan go public tahun 2016-2018 yang listing di Jakarta Islamic Index (JII). Populasi penelitian ini adalah Emiten yang tergabung dalam Jakarta Islamic Index. Sampel adalah bagian dari jumlah karakteristik yang dimiliki oleh populasi (Sugiyono, 2017: 62). Metode pengambilan sampel pada penelitian ini menggunakan metode purposive sampling, dengan kriteria: 1). Perusahaan yang sudah go public yang listing di Jakarta Islamic Index (JII) selama periode 2016-2018; 2). Perusahaan mempublikasikan laporan keuangan tahunan yang telah diaudit dalam website Jakarta Islamic Index (JII) selama periode 2016-2018; 3). Perusahaan yang konsisten listing di Jakarta Islamic Index periode 2016-2018. 4); Data yang berkaitan dengan variabel penelitian tersedia dengan lengkap. Berdasarkan metode purposive sampling diperoleh sampel yang memenuhi kriteria sebanyak 51 sampel.

Pengujian hipotesis Determinan Islamic Social Reporting (ISR) menggunakan analisis regresi data panel, dengan mempergunakan program STATA 14.2. Pengujian ini dilakukan untuk mengetahui pengaruh antara ISR dari variabel bebasnya. Model persamaan penelitian ini adalah:

ISR $=\alpha+\beta 1 S I Z E+\beta 2$ PROFIT $-\beta 3 \mathrm{LEV}+\beta 4 \mathrm{UDKI}+\beta 5 \mathrm{AGE}+\varepsilon$

Prosedur analisis data diawali dengan pemilihan metode estimasi model regresi dengan menggunakan data panel. Dalam metode estimasi model regresi dengan menggunakan data panel dapat dilakukan dengan tiga pendekatan yaitu Pooled Least Square (PLS), Fixed Effect Model, dan Random Effect Model.

Penentuan metode estimasi regresi data panel adalah berdasarkan beberapa uji yaitu:

1. Uji chow untuk menentukan model apakah Common Effect (CE) atau Pooled Least Square ataukah Fixed Effect (FE) yang paling tepat digunakan dalam mengestimasi data panel.

2. Uji hausman adalah pengujian statistik untuk memilih apakah model fixed effect atau random effect yang paling tepat digunakan.

3. Uji langrange multiplier adalah uji untuk mengetahui apakah model random effect lebih baik daripada metode common effect (CE) digunakan.

Penentuan metode estimasi regresi data dapat digambarkan pada Gambar 3.

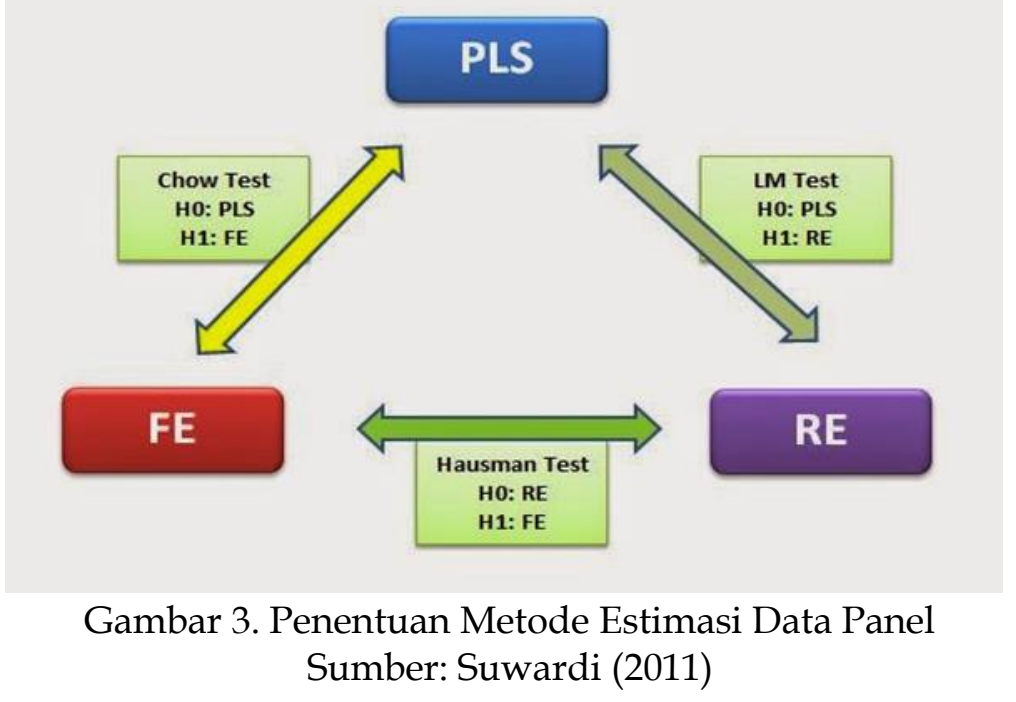




\section{HASIL DAN PEMBAHASAN}

\subsection{Gambaran Umum}

Analisis dan pembahasan yang tersaji dalam bab ini akan menunjukkan hasil dari analisis data berdasarkan pengamatan variabel dependen maupun variabel independen untuk mengetahui pengaruh ukuran perusahaan, profitabilitas, leverage, ukuran dewan komisaris independen dan umur perusahaan terhadap pengungkapan Islamic Social Reporting (ISR) dengan menggunakan analisis regresi linier berganda. Populasi yang digunakan dalam penelitian ini adalah perusahaan yang listing di Jakarta Islamic Index (JII). Sampel yang digunakan dalam penelitian ini dipilih dengan menggunakan metode purposive sampling, sehingga sampel dari penelitian ini merupakan representasi dari populasi yang ada. Berdasarkan kriteria sampel diperoleh sampel penelitian sebanyak 17 perusahaan dikali tiga tahun penelitian dari periode 2016 hingga periode 2018 sehingga menjadi 51 data penelitian.

\subsection{Hasil Statistik Deskriptif}

Berdasarkan 51 data penelitian tersebut, dilakukan summary data panel untuk mendapatkan deskripsi data. Adapun hasilnya dapat dilihat pada Tabel 1 sebagai berikut:

Tabel 1

Hasil Uji Statistik Deskriptif

\begin{tabular}{|l|r|r|r|l|l|}
\hline & N & \multicolumn{1}{l|}{ Min } & Max & Mean & Std. Deviation \\
\hline ISR & 51 & .52 & .74 & .6369 & .05446 \\
\hline SIZE & 51 & 29.21 & 33.47 & 31.3692 & 1.00456 \\
\hline PROFIT & 51 & .00 & 1.36 & 2384 & 0.32660 \\
\hline LEV & 51 & .17 & 2.65 & 1.0586 & 0.64367 \\
\hline AGE & 51 & 6 & 36 & 20.4706 & 8.89124 \\
\hline UDKI & 51 & 1 & 4 & 2.3922 & .60261 \\
\hline
\end{tabular}

Pada tabel 1 di atas dijelaskan bahwa jumlah data $(\mathrm{N})$ yang digunakan sebanyak 51 data. Variabel ISR (Y) mempunyai jumlah rata-rata yaitu sebesar 0,6369 atau sekitar 63,69\%. Secara keseluruhan, standar deviasi variabel ISR sebesar 0,05446 atau 5.4\%. Hal ini berarti terdapat persebaran data sebesar 5.4\% dari nilai rata-rata.

Ukuran Perusahaan/Size (X1) diproksikan dengan natural logaritma total aset, menunjukkan bahwa ukuran perusahaan paling kecil memiliki total aset sebanyak Rp 4.858.878.000.000, ukuran perusahaan paling besar memiliki total aset sebanyak Rp 344.711.000.000.000.. Sedangkan rata-rata ukuran perusahaan memiliki total aset sebanyak Rp 68.094.046.992.813. Standar deviasi ukuran perusahaan sebesar Rp 75.240.132.775.250 yang berarti terdapat sebaran data $\mathrm{Rp} 75.240 .132 .775 .250$ total aset dari rata-rata total aset secara keseluruhan.

Profitabilitas/Profit (X2) diproksikan dengan Return On Equity (ROE). Variabel Profit mempunyai nilai rata-rata sebesar 0,2384 atau $23,84 \%$. Hal ini berarti ratarata perusahaan mampu menghasilkan laba setelah pajak hingga 23,84\% dari total aset yang dimiliki perusahaan. Nilai standar deviasinya sebesar 0.32660 . Nilai minimumnya sebesar 0,00 atau $0 \%$, dan nilai maksimumnya sebesar 1,3 atau $130 \%$, yang berarti terdapat perusahaan dalam sampel yang mampu memperoleh laba setelah pajak sebesar $130 \%$ dari total. 
Leverage/Lev (X3) diproksikan dengan DER (Debt Equity Ratio). Nilai rata-rata DER sebesar 1,0586, nilai maksimumnya sebesar 2,65 dan minimumnya sebesar 0,17. Sedangkan angka standar deviasi yang dihasilkan adalah 0,64367. Nilai rata-rata DER sebesar $105,86 \%$ menandakan bahwa rata-rata perusahaan yang menjadi sampel dalam penelitian ini menggunakan hutang untuk membiayai perusahaan. Nilai minimum menunjukkan adanya perusahaan yang hanya menggunakan hutang sebesar $17 \%$. Sedangkan nilai maksimum sebesar $265 \%$ menunjukkan adanya perusahaan yang menggunakan hutang yang tinggi untuk membiayai perusahaan.

Umur Perusahaan/Age (X4), menunjukkan umur perusahaan minimal atau paling muda dalam penelitian ini adalah umur 6 tahun, dan umur maksimal atau paling tua adalah umur 36 tahun. Sedangkan rata-rata umur perusahaan adalah 20,47 tahun. Standar deviasi umur perusahaan sebesar 8,9 tahun, yang berarti terdapat sebaran data 8,9 tahun dari rata-rata umur perusahaan secara keseluruhan.

Ukuran Dewan Komisaris Independen/UDKI (X5) diproksikan dengan jumlah dewan komisaris independen yang dimiliki perusahaan, menunjukkan jumlah dewan komisaris independen minimal yang dimiliki perusahaan sebanyak 1 orang, dan jumlah maksimal sebesar 4 orang. Sedangkan jumlah dewan komisaris independen perusahaan rata-rata sebanyak 2,39 orang. Standar deviasi jumlah dewan komisaris independen perusahaan dalam penelitian ini adalah sebanyak 0,6 orang, yang berarti terdapat sebaran 0,6 orang dewan komisaris indepeden dari rata-rata jumlah dewan komisaris independen perusahaan secara keseluruhan.

\subsection{Penentuan Pilihan Model Regresi Data Panel}

\subsubsection{Penentuan Pilihan Model antara Pooled Least Square dengan Fixed Effect Model}

Untuk menentukan pilihan model yang terbaik antara PLS dan FE, maka dilakukan Chow Test. Adapun hasil chow test dapat dilihat pada gambar 4 . Karena P value $($ Prob > F) < alpha 0,05 $(0,0456<0,05)$, maka H1 diterima, yang artinya pilihan yang terbaik adalah FE, dibandingkan dengan PLS.

\begin{tabular}{r|rrrrrr}
\hline isr & Coef. & Std. Err. & $t$ & P $>|t|$ & [958 Conf. Interval] \\
\hline size & .0232525 & .0068297 & 3.40 & 0.001 & .0094792 & .0370259 \\
roe & .0030331 & .0297752 & 0.10 & 0.919 & -.0570144 & .0630805 \\
lev & -.0229088 & .0118233 & -1.94 & 0.059 & -.0467527 & .0009352 \\
age & -.0004446 & .0008258 & -0.54 & 0.593 & -.0021099 & .0012208 \\
udki & .0201318 & .01139 & 1.77 & 0.084 & -.0028382 & .0431019 \\
_cons & -.1080801 & .2175444 & -0.50 & 0.622 & -.5468002 & .3306401 \\
\hline sigma_u & .01968512 & & & & & \\
sigma_e & .04359679 & & & & & \\
rho & .16934993 & (fraction of variance due to u_i) &
\end{tabular}

F test that all $u_{-} i=0: F(2,43)=3.32 \quad$ Prob $>F=0.0456$

Gambar 4. Hasil Chow Test

Sumber: Data yang diolah, 2020

\subsubsection{Penentuan Pilihan antara Fixed Effect Model dengan Random Effect Model}

Berdasarkan uji chow, pilihan model terbaik adalah pada FE. Karena pilihan jatuh pada FE, maka selanjutnya dilakukan hausman test untuk menguji manakah model yang lebih baik antara FE atau RE. Hasil hausman test dapat dilihat pada Gambar 5. 


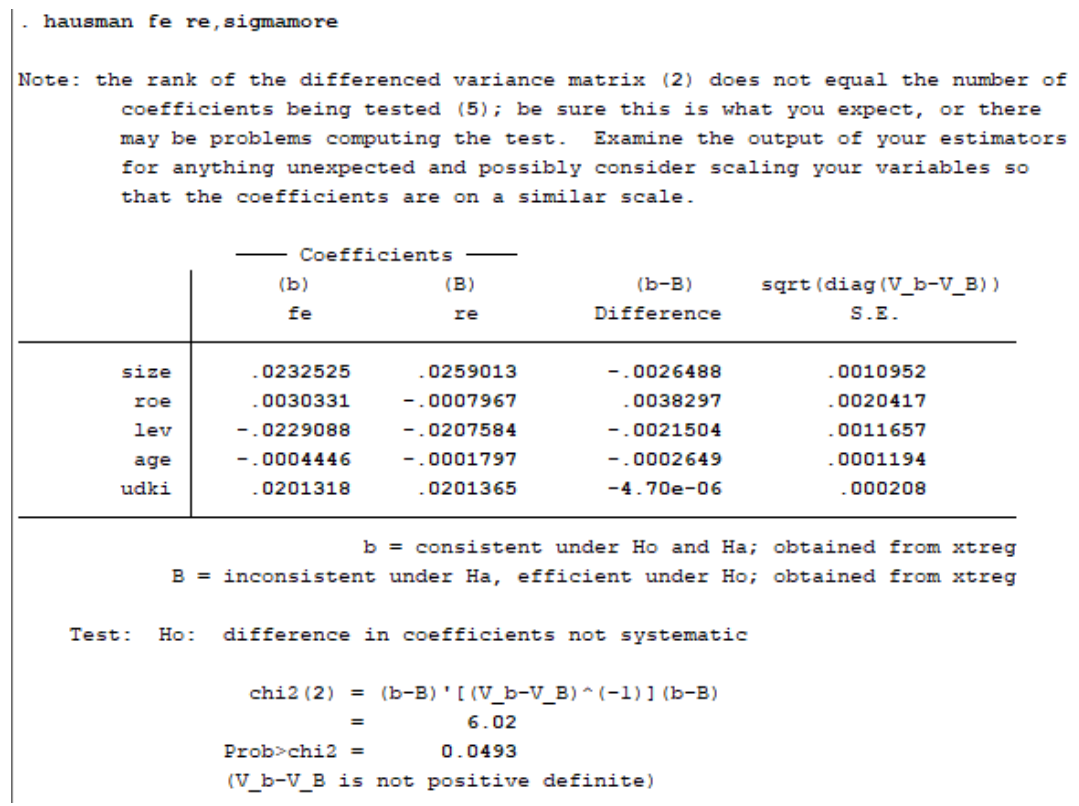

Gambar 5. Hasil Hausman Test

Sumber: Data yang diolah, 2020.

Berdasarkan gambar 5, maka pilihan terbaik adalah FE dari pada RE, karena $\mathrm{p}$ value (Prob $>$ Chi2) < alpha 0,05 $(0,0493<0,05)$.

\subsubsection{Penentuan Pilihan antara Pooled Least Square dengan Random Effect Model}

Berdasarkan uji chow dan uji hausman, pilihan model terbaik adalah pada FE, sehingga pilihan model yang terbaik sudah dapat ditentukan, yaitu FE. Namun demikian, Langrange Multiplier Test akan dilakukan untuk melihat model yang terbaik antara PLS ataukah RE. Hasil LM Test dapat dilihat pada Gambar 6.

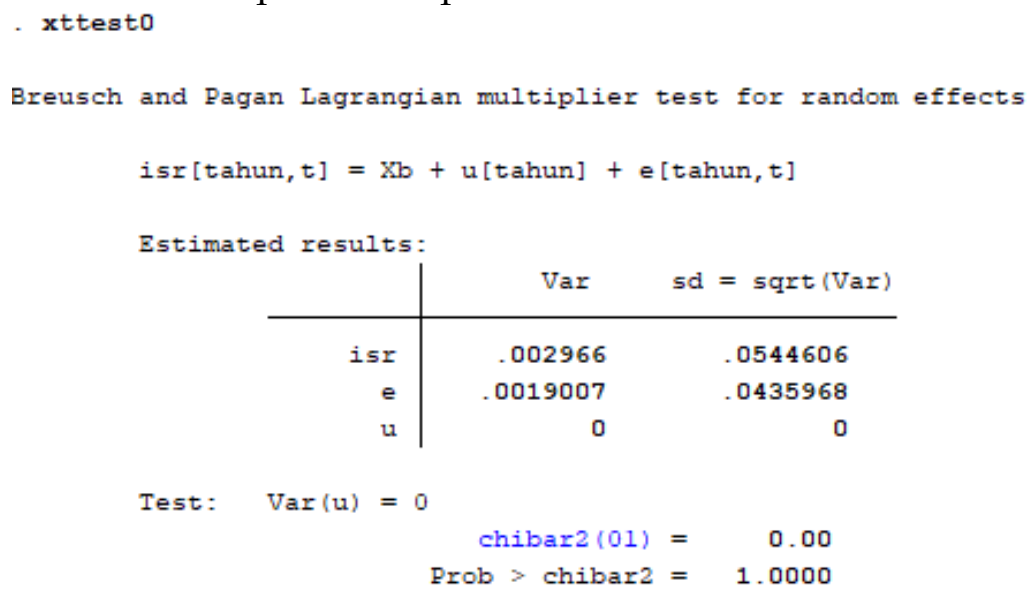

Gambar 5. Hasil Langrange Multiplier Test

Sumber; Data yang diolah, 2020

Berdasarkan gambar 6, maka pilihan terbaik adalah PLS dibandingkan dengan RE, karena $\mathrm{p}$ value (Prob $>$ chibar2) $>$ alpha 0,05 . Hasil ini tidak mengubah hasil sebelumnya yang menyatakan bahwa FE adalah model yang terbaik dibandingkan dengan PLS dan RE. Dengan demikian, model yang dihasilkan dengan metode FE akan dilanjutkan guna interpretasi. 


\subsection{Uji Asumsi Klasik}

Pemilihan model FE sebagai model yang terbaik dibandingkan dengan PLS ataupun RE, tetap berasumsi BLUE, sehingga harus dilakukan pengujian terhadap asumsi klasik. Pada tabel 2 berikut, disajikan hasil uji asumsi klasik, yaitu uji normalitas, uji multikolinieritas, uji heteroskedastisitas, dan uji autokorelasi

Tabel 2. Hasil Uji Asumsi Klasik.

\begin{tabular}{|c|c|c|c|}
\hline Uji Asumsi Klasik & & Kriteria & Kesimpulan \\
\hline $\begin{array}{l}\text { Uji Multikolinieritas } \\
\text { Variabel }\end{array}$ & $1 / \mathrm{VIF}$ & & \\
\hline $\begin{array}{l}\text { Size } \\
\text { UDKI } \\
\text { Age } \\
\text { Lev } \\
\text { ROE }\end{array}$ & $\begin{array}{l}0.029907 \\
0.047606 \\
0.112487 \\
0.177202 \\
0.275681\end{array}$ & $\begin{array}{l}\text { 1/VIF } 0.01 \text { atau } \\
\text { kurang } \\
\text { mengindikasikan } \\
\text { Multikolinieritas }\end{array}$ & $\begin{array}{l}\text { Lolos Uji } \\
\text { Multikolinieritas }\end{array}$ \\
\hline $\begin{array}{l}\text { Uji Heteroskedastisitas } \\
\text { Prob }>\text { Chi2 }\end{array}$ & 0,0864 & $\begin{array}{l}\text { Heteroskedastisitas } \\
\text { jika (Prob Chi2) < } \\
\text { alpha }\end{array}$ & $\begin{array}{l}\text { Lolos Uji } \\
\text { Heteroskedastisitas }\end{array}$ \\
\hline $\begin{array}{l}\text { Uji Autokorelasi } \\
\text { Prob > F }\end{array}$ & 0.1166 & $\begin{array}{l}\text { Autokorelasi jika } \\
(\text { Prob }>\text { F })<\text { alpha }\end{array}$ & $\begin{array}{ll}\text { Lolos } & \text { Uji } \\
\text { Autokorelasi } & \\
\end{array}$ \\
\hline $\begin{array}{l}\text { Uji Normalitas } \\
\text { Prob > z }\end{array}$ & 0.16269 & $\begin{array}{l}\text { Tidak normal jika } \\
(\text { Prob }>\text { z) }<0.05\end{array}$ & Lolos Uji Normalitas \\
\hline
\end{tabular}

Sumber: Data diolah, 2020

Berdasarkan hasil uji asumsi klasik pada tabel 2, maka dapat disimpulkan bahwa Model Panel bersifat BLUE, dan layak untuk diinterpretasikan.

\subsection{Uji Hipotesis}

Berikut ini disajikan Tabel 3, hasil uji regresi data panel fixed effect model (FE):

Tabel 3

Analisis Regresi Linier Berganda

\begin{tabular}{|l|l|l|l|}
\hline \multicolumn{1}{|c|}{ Variabel } & \multicolumn{1}{|c|}{ Koefisien } & \multicolumn{1}{c|}{ Prob. } \\
\hline 1 (constant) & -.1080801 & -0.50 & 0.622 \\
\hline SIZE & .0232525 & 3.40 & $0.001^{* * *}$ \\
\hline ROE & .0030331 & 0.10 & 0.919 \\
\hline LEV & -.0229088 & -1.94 & $0.059^{*}$ \\
\hline AGE & -.0004446 & -0.54 & 0.593 \\
\hline UDKI & .0201318 & 1.77 & $0.084^{*}$ \\
\hline $\begin{array}{l}\text { R-square: } 0.3607 \\
\text { Prob.(F-Statistik): } 0.0009\end{array}$ & \multicolumn{5}{l}{} \\
\hline
\end{tabular}

Sumber: Data yang diolah, 2019

Ket: ${ }^{* * *}$ ) signifikan di level 1\%; *) signifikan di level 10\%

Berdasarkan tabel 3 dapat dilihat hasil perhitungan regresi linier berganda dalam penelitian ini sebagai berikut:

ISR = -0,1081 + 0,0233 SIZE + 0,003 ROE - 0,023 LEV + 0,020 UDKI - 0,0004 AGE

Berdasarkan persamaan regresi di atas, dapat dilihat pengaruh masingmasing variabel independen terhadap variabel dependen. Konstanta persamaan regresi bernilai negatif sebesar -0,198. Berarti jika nilai dari variabel-variabel independen sebesar 0 (konstan) maka nilai variabel dependen (ISR) sebesar -0,108. Koefisien regresi variabel ukuran perusahaan bernilai positif sebesar 0,0233, artinya peningkatan umur perusahaan 
sebesar satu satuan akan terjadi peningkatan pengungkapan ISR sebesar 0,0233 dengan asumsi variabel independen lain konstan. Koefisien regresi variabel profitabilitas bernilai negatif sebesar 0,003, artinya penurunan profitabilitas sebesar satu satuan akan terjadi peningkatan pengungkapan ISR 0,003 dengan asumsi variabel independen lain konstan. Koefisien regresi variabel leverage bernilai negatif sebesar 0,023 , artinya penurunan leverage sebesar satu satuan akan terjadi peningkatan pengungkapan ISR sebesar 0,023 dengan asumsi variabel independen lain konstan. Koefisien regresi variabel ukuran dewan komisaris independen bernilai positif sebesar 0,020, artinya peningkatan profitabilitas sebesar satu satuan akan terjadi peningkatan pengungkapan ISR sebesar 0,020 dengan asumsi variabel independen lain konstan. Koefisien regresi variabel umur perusahaan bernilai negatif sebesar 0,0004, artinya peningkatan umur perusahaan sebesar satu satuan akan terjadi peningkatan pengungkapan ISR sebesar 0,0004 dengan asumsi variabel independen lain konstan.

\subsection{Uji Koefisien Determinasi $\left(\mathbf{R}^{2}\right)$}

Dari tabel 3 hasil uji regresi didapatkan angka $R$ square 0,3607. Hal ini berarti bahwa ada kontribusi sebesar 36,07\% dalam memprediksi ISR yang dijelaskan oleh Ukuran perusahaan (Size), Profitabilitas (Profit), Leverage (Lev), Umur Perusahaan (Age) dan Ukuran Dewan Komisaris (UDKI) secara bersama-sama. Sedangkan sisanya $(100 \%$ $36,07 \%=63,93 \%)$ dijelaskan oleh sebab-sebab yang lain di luar variabel yang diteliti.

\subsection{Uji Kelayakan Model (Uji-F)}

Uji-F digunakan untuk menguji koefisien regresi secara bersama-sama. Dengan kata lain, Uji-F dilakukan untuk mengetahui apakah variabel bebas secara bersama-sama mempengaruhi variabel terikat. Uji-F juga dapat dilakukan dengan membandingkan probabilitas statistik $\mathrm{F}$ dengan tingkat signifikansi (a) 0,05, apabila:

a. Probabilitas statistik $\mathrm{F}<0,05$, maka model regresi tersebut dapat digunakan untuk menguji signifikansi antarvarians.

b. Probabilitas statistik F $>0,05$, maka model regresi tersebut tidak dapat digunakan untuk menguji signifikansi antar varians.

Dari tabel 3 diketahui angka signifikansi sebesar 0,0009 lebih kecil dibandingkan taraf signifikansi $a=5 \%$ artinya model fit pengaruh Ukuran perusahaan (Size), Profitabilitas (Profit), Leverage (Lev), Umur perusahaan (Age) dan Ukuran Dewan Komisaris Independen (UDKI) berpengaruh signifikan secara simultan atau bersamaan terhadap ISR $(Y)$.

\subsection{Pembahasan}

\subsubsection{Pengaruh Ukuran Perusahaan terhadap ISR}

Ukuran perusahaan berpengaruh positif dan signifikan terhadap pengungkapan tanggung jawab sosial berbasis Islam (Islamic Social Reporting). Teori stakeholders mendukung hubungan positif ukuran perusahaan terhadap ISR, dimana semakin kuat stakeholder, semakin pula penyesuaian (informasi) yang harus diberikan perusahaan kepada stakeholder-nya. Suhardjanto dan Wardhani (2010) mengatakan bahwa ukuran perusahaan merupakan prediktor yang mempengaruhi tingkat sosial ekonomis yang besar terhadap lingkungannya, sehingga lebih menjadi sorotan pemangku kepentingan (stakeholders). Maka dari itu, perusahaan dituntut untuk semakin banyak mengungkapkan informasi, termasuk mengenai kinerja sosial perusahaan.

Perusahaan yang lebih besar adalah perusahaan yang memiliki sumber daya lebih banyak daripada perusahaan yang lebih kecil sehingga memiliki dana untuk 
membuat laporan informasi perusahaan. Selain itu, semakin besar ukuran perusahaan, biasanya informasi yang tersedia untuk investor dalam pengambilan keputusan sehubungan dengan investasi dalam perusahaan tersebut semakin banyak (Siregar dan Utama, 2005). Hasil penelitian ini sesuai dengan penelitian sebelumnya oleh Ayu (2010), Raditya (2012), Maulida dkk (2014), Firmansyah \& Eko Haryanto (2014), Putri \& Yuyetta E.N.A (2014), Rama \& Meliawati (2014), Santoso \& Zaki (2017), Rizfani \& Lubis (2018).

\subsubsection{Pengaruh Profitabilitas terhadap ISR}

Profitabilitas tidak berpengaruh terhadap pengungkapan ISR. ISR merupakan suatu kebutuhan stakeholder, terutama stakeholder muslim. Perusahaan beranggapan ketika kondisi keuangan mengalami profit maupun rugi, perusahaan akan tetap melakukan dan mengungkapkan ISR. Sehingga perusahaan akan mendapat legitimasi dari stakeholder. Hal ini merupakan wujud dari akuntabilitas kepada Allah SWT dan masyarakat serta memenuhi kebutuhan stakeholder muslim dalam pengambilan keputusan. Hal ini juga dinyatakan Rivai et al (2012) dalam manajemen berorientasi syariah Islam, organisasi atau perusahaan bertujuan tidak hanya untuk mencari profit setinggi-tingginya, namun juga harus memberikan benefit kepada internal organisasi dan eksternal (lingkungan).

Hasil penelitian ini sejalan dengan penelitian yang dilakukan oleh Purwani et al., (2018), Santoso (2018), Sunarsih dan Ferdiansyah (2016), Arianugrahini dan Firmansyah (2020) yang menyimpulkan bahwa profitabilitas suatu perusahaan tidak memiliki pengaruh dalam pengungkapan ISR, hal tersebut karena bahwa perusahaan memiliki perspektif yang berbeda dengan ISR.

\subsubsection{Pengaruh Leverage terhadap ISR}

Leverage berpengaruh negatif dan signifikan terhadap pengungkapan ISR. Rasio leverage menggambarkan sampai sejauh mana aktiva suatu perusahaan dibiayai oleh hutang. Rasio leverage digunakan untuk mengukur kemampuan suatu entitas untuk menyelesaikan semua kewajibannya kepada para stakeholders. Dengan tingkat leverage yang besar kemungkinan perusahaan akan mengalami pelanggaran terhadap kontrak utang, maka manajer akan berusaha untuk melaporkan laba sekarang lebih tinggi, supaya laba yang dilaporkan tinggi maka manajer harus mengurangi biaya-biaya termasuk biaya untuk pengungkapkan Islamic Social Reporting. Sebagai upaya menaikan nilai laba, perusahaan membutuhkan tambahan modal dari kreditur atau investor. Pihak kreditur atau investor akan menilai tingkat akuntabilitas dan transparansi perusahaan dalam kegiatan operasionalnya sebelum memberikan pinjaman atau menanamkan modalnya. Maka dengan demikian agar mendapat simpati dari pihak kreditur dan investor maka aspek akuntabilitas dan transparansi menjadi hal yang ditonjolkan pihak perusahaan sehingga hal ini menyebabkan semakin tinggi rasio leverage suatu perusahaan mempengaruhi secara negatif tingkat pengungkapan ISR.

Sesuai dengan teori stakeholders, semakin kuat stakeholder, semakin pula penyesuaian (informasi) yang harus diberikan perusahaan kepada stakeholders- nya. Oleh sebab itu semakin tinggi tingkat leverage, perusahaan akan mengurangi informasi perusahaan. Sejalan dengan hasil penelitian ini dimana rata-rata perusahaan menggunakan rasio leverage yang tergolong tinggi hingga 105,86\% aktivitas perusahaan dibiayai oleh hutang. Menurut Peraturan Menteri Keuangan No. 169/PMK.010/2015 tentang Penentuan Besarnya Perbandingan Antara Utang dan Modal Perusahaan Untuk Keperluan Penghitungan Pajak Penghasilan pasal 1 ayat (1) bahwa "Besarnya perbandingan antara utang dan modal sebagaimana dimaksud dalam Pasal 1 ayat (1) ditetapkan paling tinggi sebesar empat dibanding satu (4: 1)". Ini berarti besaran utang lebih dari $80 \%$ dianggap 
tidak wajar dan tidak bisa dibebankan sebagai biaya. Atas dasar peraturan ini rata-rata penggunaaan hutang untuk kegiatan perusahaan tergolong sudah tidak wajar sebab hingga mencapai rata-rata $105,86 \%$. Hal ini kemudian berpengaruh negatif terhadap ISR yakni pengungkapan informasi perusahaan dalam penelitian ini masih tergolong sempit atau masih tergolong rendah yakni hanya rata-rata $54,2 \%$ pengungkapan ISR. Hal ini sesuai dengan penelitian sebelumnya yang dilakukan oleh Rama \& Meliawati (2014), Rizfani \& Lubis (2018).

\subsubsection{Pengaruh Ukuran Dewan Komisaris Independen terhadap ISR}

Ukuran dewan komisaris independen berpengaruh positf terhadap pengungkapan ISR. Salah satu tugas dewan komisaris independen adalah memberikan laporan mengenai pelaksanaan tugas pengawasan dan pemberian nasihat yang dilakukan dalam laporan tahunan serta menelaah dan menyetujui laporan tahunan tersebut. Semakin banyak jumlah dewan komisaris maka semakin luas informasi perusahaan yang diungkapkan. Alasan yang mendasarinya berkaitan dengan teori agensi, dimana dewan komisaris sebagai pihak yang independen dan netral dalam perusahaan diharapkan mampu menjembatani adanya asimetri informasi yang terjadi antara pihak pemilik dengan pihak manajer dengan mendorong anggota dewan komisaris lain untuk melakukan tugas pengawasan lebih baik lagi. Jika pengawasan telah dilakukan secara efektif maka pengelolaan perusahaan akan dilakukan dengan baik dan manajemen akan mengungkapkan semua informasi yang ada (White et al.,2007).

Said et al., (2009) menyatakan bahwa semakin besar jumlah anggota dewan komisaris, maka akan semakin mudah untuk mengendalikan CEO dan monitoring yang dilakukan akan semakin efektif. Dikaitkan dengan pengungkapan tanggung jawab sosial, maka tekanan terhadap manajemen juga akan semakin besar untuk mengungkapkannya. selaras dengan penelitian Firmansyah \& Eko Haryanto (2014).

\subsubsection{Pengaruh Umur Perusahaan terhadap ISR}

Umur perusahaan tidak berpengaruh terhadap pengungkapan ISR. Penelitian ini tidak dapat membuktikan bahwa perusahaan dengan umur yang lebih tua pasti melakukan pengungkapan tanggung jawab sosial secara syariah lebih luas dibandingkan perusahaan dengan umur yang lebih muda. Hasil penelitian menunjukkan implikasi bahwa perusahaan lama atau baru, tidak menganggap stakeholder sebagai kelompok atau individu yang dapat mempengaruhi atau dipengaruhi oleh aktivitas perusahaan, sehingga merasa tidak memiliki kewajiban untuk melakukan pengungkapan aktivitas ISR secara baik. Hal ini tidak sejalan dengan teori stakeholder yang menyatakan bahwa stakeholder merupakan kelompok atau individu yang dapat mempengaruhi atau dipengaruhi oleh aktivitas perusahaan. Dengan kata lain, perusahaan dengan umur yang lebih tua memungkinkan untuk melakukan pengungkapan tanggung jawab sosial secara syariah lebih sempit dan perusahaan dengan umur yang lebih muda juga memungkinkan untuk melakukan pengungkapan tanggung jawab sosial secara syariah lebih luas. Beberapa perusahaan dengan umur yang lebih tua melakukan pengungkapan tanggung jawab sosial secara syariah lebih sempit karena perusahaan tersebut masih memiliki kesadaran yang rendah terhadap tanggung jawab sosial secara syariah. Selain itu, perusahaan dengan umur yang lebih tua tidak dapat dipastikan bahwa perusahaan tersebut merupakan perusahaan besar yang dianggap telah memiliki pembiayaan, fasilitas, dan sumber daya manusia yang lebih memadai sehingga mampu melakukan pengungkapan lebih luas. Beberapa perusahaan dengan umur yang lebih muda kemungkinan melakukan pengungkapan tanggung jawab sosial secara syariah lebih luas dengan tujuan untuk 
mengurangi ketidakpastian risiko dan meningkatkan kepercayaan investor, khususnya investor Muslim, terhadap posisi mereka. Hasil penelitian ini sesuai dengan penelitian sebelumnya oleh Raditya (2012)

\section{KESIMPULAN}

Penelitian ini bertujuan untuk menguji pengaruh ukuran perusahaan, profitabilitas, levarage, ukuran dewan komisaris dan umur perusahaan yang listing di Jakarta Islamic Index terhadap pengungkapan Islamic Social Reporting (ISR). Berdasarkan hasil pengujian yang telah dilakukan, dapat disimpulkan beberapa hal yaitu:

1. Berdasarkan hasil pengujian, dapat diketahui bahwa variabel ukuran perusahaan beperngaruh positif dan signifikan terhadap ISR.

2. Variabel profitabilitas tidak berpengaruh terhadap pengungkapan ISR

3. Variabel Leverage berpengaruh negatif dan signifikan terhadap pengungkapan ISR.

4. Variabel umur perusahaan tidak berpengaruh terhadap pengungkapan ISR.

5. Ukuran dewan komisaris independen berpengaruh positif terhadap pengungkapan ISR.

Setelah melakukan analisis penelitian, diketahui bahwa penelitian ini memiliki keterbatasan penelitian sebagai berikut:

1. Penelitian ini dilakukan hanya untuk periode tahun 2016 sampai 2018. Periode pengamatan relatif terlalu singkat untuk dapat mengestimasi pengaruh variabel independen terhadap dependennya.

2. Sampel yang digunakan hanya menggunakan perusahaan syariah yang listing di Jakarta Islamic Index (JII).

Penelitian selanjutnya dapat menggunakan daftar perusahaan yang masuk dalam Indonesia Sharia Stock Index (ISSI) atau Daftar Efek Syariah. Dengan menggunakan indeks tersebut, penelitian selanjutnya diharapkan dapat lebih menggambarkan kondisi pasar modal Syariah Indonesia yang sebenarnya.

Dalam hal menentukan indeks pengungkapan ISR, seharusnya dapat menggunakan sumber data yang lebih variatif untuk meningkatkan akurasi pengukuran ISR. Beberapa media alternatif selain laporan keuangan yang dapat digunakan dalam menilai pengungkapan ISR adalah seperti publikasi media massa, website, atau menggali data dari sumber-sumber lainnya. 


\section{DAFTAR PUSTAKA}

Arianugrahini I and Firmansyah EA. (2020). Determinan Pengungkapan Islamic Social Reporting (ISR) pada Bank Umum Syariah (BUS) di Indonesia (Determinants of Islamic Social Reporting (ISR) Disclosure at Islamic Commercial Banks in Indonesia). Perisai : Islamic Banking and Finance Journal. 4:2. doi: 10.21070/perisai.v4i2.841

Firmansyah, I., \& Haryanto, E. (2014). Analisis Pengungkapan Kinerja Sosial (Social Disclosure) Pebankan Syariah Di Indonesia Dan Malaysia Dalam Perspektif Islamic Social Reporting. Buletin Ekonomi.

Haniffa, R. (2002). Social Reporting Disclosure: An Islamic Perspective. Indonesian Management and Accounting Research, 1(2).

Haniffa, R., \& Hudaib, M. (2007). Exploring ethical identity of Islamic banks via communication in annual reports. Journal of Business Ethics, 76, 97-116.

Maali, B., Casson, P., \& Napier, C. (2006). Social Reporting by Islamic Banks. ABACUS, 42(2), 266-289.

Othman, R., \& Thani, A. M. (2010). Islamic Social Reporting Of Listed Companies In Malaysia. International Business \& Economics Research Journal, 12, 135-144.

Prasetyaningrum, Ari Kristin. (2018). Pengaruh Ukuran Perusahaan, Profitabilitas, Leverage, Efisiensi Biaya, Dan Umur Perusahaan Terhadap Islamic Social Reporting (ISR) Pada Perbankan Syariah Di Indonesia. MALIA:Journa of Islamic Banking and Finance. 147-162.

Purwani, T., Nurlaela, and Siti, A. W. (2018). The Influence of Company Size, Profitability , Liquidity, Leverage and Tax Avoidance Disclosure Against the Islamic Social Reporting on Companies Listed OnThe Indonesian Stock Index of Sharia. The 2nd International Conference on Technology, 39-47.

Putri, T. K., \& Yuyetta, E. N. A. (2014). Faktor-Faktor yang Mempengaruhi Islamic Social Reporting Perusahaan-Perusahaan yang Terdaftar pada Indeks Saham Syariah ndonesia (ISSI) Tahun 2011-2012. Diponegoro Journal of Accounting, 3(2).

Rahayu, R. S. (2014). Faktor-Faktor Yang Mempengaruhi Pengungkapan Corporate Social Responsibility (CSR) Pada Perbankan Syariah. JRAK, 5(2).

Rama, A., \& Meliawati. (2014). Analisis Deteminan Pengungkapan Islamic Social Reporting: Studi Kasus Bank Umum Syariah di Indonesia. Equilibrium, 2(1).

Rina Trisnawati, \& Azhar, F. A. (2013). Pengungkapan Islamic Social Reporting Pada Bank Syariah Di Indonesia. Proceeding Seminar Nasional.

Rizfani, K. N., \& Lubis, D. (2018). Pengungkapan Islamic Social Reporting pada Perusahaan di Jakarta Islamic Index. Jurnal Al-Muzara'ah, 6(2).

Rosiana, R., Arifin, B., \& Hamdani, M. (2015). Pengaruh Ukuran Perusahaan, Profitabilitas, Leverage, dan Islamic Governance Score Terhadap Pengungkapan Islamic Social Reporting (Studi Empiris pada Bank Umum Syariah di Indonesia Tahun 20102012). Jurnal Bisnis Dan Manajemen, 5(1). https://doi.org/https://doi.org/10.15408/ess.v5i1.2334

Santoso, A., \& Dhiyaul-Haq, Z. (2017). Determinan Pengungkapan Islamic Social Reporting pada Bank Umum Syariah di Indonesia. Jurnal Dinamika Akuntansi Dan Bisnis, 4, 125. https:// doi.org/10.24815/jdab.v4i2.6421

Santoso, N. (2018). State-of-the-Art Theories and Empirical Evidence. State-ofthe-Art Theories and Empirical Evidence. https:// doi.org/10.1007/978-981-10-6926-0.

Sembiring, E. R. (2003). Kinerja Keuangan, Political Visibility, Ketergantungan pada Hutang, dan Pengungkapan Tanggung Jawab Sosial Perusahaan. Simposium 
Nasional Akuntansi 6, 249-259.

Sugiyono. (2017). Metode Penelitian Kuantitatif, Kualitatif dan RED. Alfabeta.

Sunarsih, U. and Ferdiansyah, F. (2016). Determinants of The Islamic Social Reporting Disclosure. Al-Iqtishad: Journal of Islamic Economics 9, 69-80. doi: 10.15408/aiq.v9i1.3771.

Sutapa, \& Laksito, H. (2018). Peran Islamic Social Reporting Terhadap Nilai Perusahaan. Jurnal Akuntansi Indonesia, 7(1).

Suwardi, A. (2011). Modul Stata: Tahapan dan Perintah (Syntax) Data Panel (2011th ed.). Lab. Komputasi Departemen Ilmu Ekonomi Fakultas Ekonomi Universitas Indonesia. 